\section{The Relation Between Social Learning and Visual Culture*}

\author{
Meliha Yılmaza , Uğur Yılmaz, ${ }^{\text {,**}}$, Ece Nur Demir-Yılmaz
}

$\begin{array}{ll}\text { Received: } & 19 \text { November } 2018 \\ \text { Revised: } \quad 5 \text { March } 2019 \\ \text { Accepted: } \quad 22 \text { March } 2019 \\ \text { ISSN: 1307-9298 } \\ \text { Copyright @ IEJEE } \\ \text { www.iejee.com }\end{array}$

DOI: 10.26822/iejee.2019450837

\begin{abstract}
With the developing technology, acceleration of visual production and increasing of peoples' relation with generated visuals (painting, photograph, video, computer games, poster, etc.), is a situation which affect perceptual and behavioral characteristic of people. As a result of connection with generated visuals, changes at the perception and behavior of people remind social learning and visual culture terms which have relation with seeing and visuality fields. Relation between the social learning theory, which states that learning occurs through observation in social environment, and visual culture subject is a mystery. Due to this reason, the research aims to investigate relation between social learning and visual culture. Theoretical structures of the social learning and visual culture terms were pointed out in this research, and relation between these two terms were argued at theoretic level. In consequence of this research, it was seen that experiences, people obtain from connection with visual culture forms in their daily life, and social learning have connections. It was realized that visual culture forms supply vicarious livings to the observers prone to observe and imitate of behaviors that have model characteristic. It was seen that the livings, acquired observational learning from visual culture forms, is a shaping factor for individuals' attitudes and actions. In the study, it was seen that examining the visual culture as an environmental factor in the context of social learning will help to understand and illuminate the changing, transforming and deriving aspects of human behavior in the 21 st century.
\end{abstract}

Keywords: Social Learning, Visual Culture, Observational Learning

\section{Introduction}

We observe that visual forms (pictures, photos, videos, animations, computer games, movies, posters etc.) that we perceive through observation are rapidly produced, understood and consumed in the present century. The visuals, which have become an integral part of the 21 st century socio-cultural life, are all around life as an environmental factor. Mobile phones, billboards, television screens, computers, buildings, public transport stations etc., and individual and collective living spaces are surrounded by visuals. In our social life under the hegemony of visuals, our communication with the visuals is sometimes ensured by our individual choices, sometimes by non-preferential communication. Regardless of the type of communication with visuals, it is thought that visuals present various meanings to the observers in the sensory or behavioral context. This situation brings up the issues of learning through visual arts, visual learning and social learning.

Social learning is related to the experiences we get from others or from the environment through observation. The emphasis of the social learning on the environmental factor is discussed in the context of the visual forms produced by humans. Learning by observing helps to achieve faster results and more satisfactory experiences than learning by reading or listening. Therefore, in the era of visual culture, the pace and direction of learning through visuals has improved. Especially the opportunities offered by internet technology, learning and observing from the visuals, makes the subject of learning valuable and important. For this reason, as an environmental factor in the research, the relationships between the experiences we have acquired from the visual forms and our behaviors were examined in the context of social learning and visual culture.

\section{Social Learning}

Social learning theory is a learning theory positioned between behavioral learning and cognitive learning. It is known that the foundations of social learning, which is one of the cognitive-weighted behavioral learning theories, are quite old. It is possible to see the traces of social learning in the views of Plato and Aristotle, two of the famous philosophers of antiquity, on education. Plato's Cave Allegory emphasizes the actions of observation and modeling. Also, in Aristotle's famous work The Politics, it is seen that the action of sight and environmental factors have an impact on learning (Aristoteles, trans. 2010). In this study, Aristotle expressed the need of keeping children (5-7 year olds) away from the slaves as much as possible, since the young children tend to learn many things in observational and auditory way (Aristoteles, trans. 2010, p. 230). Because, according to Aristotle, observing the environment has important roles on behavior acquisition. In similar way, it is possible to see the traces of social learning in the views of the philosopher and educator John Dewey on education. According to Dewey, the relationship between people and each other is an important element in learning. Because Dewey (2004) believes that communication has an educational force on individuals in social life. It is seen that Dewey's view of the school as an integrated unit with social life, and the views of the individual on living and learning through social life are related to social learning. Also, Russian psychologist Lev Semenovich Vygotsky is one of the names that draws attention to the phenomenon of social learning. According to Vygotsky (1978), the role of the social environment on human learning cannot be ignored. Therefore, "Vygotsky gives a central role to the culture and transfer of culture through social interaction and communication while explaining the development of psychological functions" (Özbay, 2011, p. 145). Vygotsky's views of the individual on

\footnotetext{
* This study is an extended article of the study, which was presented as an oral presentation and published as an abstract in III. INES International Education and Social Science Congress, Alanya/Antalya-Turkey

b,*** Corresponding Author: Uğur Yllmaz, Aksaray University, Faculty of Education, Department of Fine Arts Education, Aksaray, Turkey. E-mail: uyilmaz.rssm@gmail.com a Meliha YIImaz, Gazi University, Faculty of Education, Department of Fine Arts Education, Ankara, Turkey. E-mail: mel.yilmaz0637@gmail.com c Ece Nur Demir-Yılmaz, Aksaray University, Faculty of Education, Department of Fine Arts Education, Aksaray, Turkey. E-mail: ecenur.dmr@hotmail.com
} 
social learning from the social environment and importance on the role of the social environment in cognitive development are related to the issue of social learning. As it is stated in all these examples, it is known that the effects of human relationships with the environment as a social being on the learning subject have been handled by different theorists in different periods.

Observation and observation processes in social learning have a basic and preliminary position. Because observation represents the first step of interpersonal relations in social life. Berger in his study (1977) states it as "seeing comes before words. The child looks and recognizes before it can speak" (p. 7). In this context, the primary role of human vision in the relationship with the social environment makes observation an essential element of social learning. The basic and preliminary role of observation in the interpersonal relations plays an important role on associating social learning theory with learning by observation phenomenon. Researchers such as Edward Lee Thorndike, John Broaud Watson, John Dollard, Neal Miller and Burrhus Frederic Skinner, who try to explain learning through observation, appear to essentially contribute to the maturation of social learning theory.

Psychologist Edward L. Thorndike is the first person to try to explain the learning through observation. Thorndike (1911) tried to explain learning by observation through experiments with animals such as cats in particular, chicks, monkeys and dogs. In the experiment, it was examined that, whether inexperienced animals would succeed in achieving out-of-box behaviors by watching experienced animals that had previously learned to come out of the puzzle box. As a result of the examination, inexperienced animals were not able to get out of the puzzle box by observing experienced animals getting out of the puzzle box. For this reason, Thorndike could not obtain any significant findings from his observational learning based experiment. Thorndike, who used monkeys in his experiment like Watson did, appears to be unable to obtain observational learning based findings (Kalkan, 2011, p. 246). Unlike Thorndike and Watson, Neal Miller and John Dollard appear to emphasize the role of reinforcer in imitating behavior and do not deny learning through observation (Senemoğlu, 2012, p. 215). According to Miller and Dollard (1979), reinforcer as a result of imitated behavior is an important element in repetition of behavior. Similar to Miller and Dollard, Burrhus Frederic Skinner observes that the observer imitates the model, makes his behavior similar to the behavior of the model, and ultimately reinforces the behavior similar to the behavior of the model. (Kalkan, 2011; Senemoğlu, 2012). All these examples that contribute to the development of social learning theory reveal roles of eyesight on learning. However, it is known that the major contribution to observational learning is given by Albert Bandura.

\section{Albert Bandura and Observational Learning}

Social learning theory is identified with the famous Psychologist Albert Bandura. Albert Bandura developed the theory of social learning during his study period at Lowa University. With many studies on social learning, Bandura's most important studies are 'Bobo Doll' experiment in 1963 and his book 'Social Learning Theory' published in 1977. Bandura states that, social behavior in relation to human behavior; cognitive, behavioral and environmental factors should be discussed in the context of the interaction (Bandura, 1977). Therefore, Bandura's views on social learning differ from those contributing to this subject. Especially Bandura draws attention to the role of 'observational learning' on social learning; observing an individual's behavior is not simply imitating it. Bandura approaches social learning in the context of both observation and cognitive factors. As it is understood from his views, the individual imitates a behavior that he observes from the social environment with cog- nitive evaluation. Therefore, the relations between personal, behavioral and environmental factors appear in Bandura's social learning theory as follows (Bandura, 1977, 1997):

\begin{tabular}{|l|l|}
\hline & $\begin{array}{l}\text { B: Personal Factors } \\
\text { B: Behavioral Factors } \\
\text { E: Environmental Factors }\end{array}$ \\
\hline
\end{tabular}

Figure 1. Relation between personal, behavioral and environmental factors according to Bandur

It is known that Albert Bandura tried to prove observational learning through the 'Bobo Doll' experiment in 1963. This experiment with the help of a toy called Bobo Doll was carried out with the participation of a group of children and a model. Basically, in the experiment the behaviors of the model playing with Bobo Doll were shown to a group of children. In the shown scene, the model hits the Bobo Doll toy with a hammer, throws it into the air, kicks it and throws it on the ground. Children participating in the experiment observed the aggressive behavior of the model on the toy. Afterwards, the children were taken to a laboratory full of toys. In this laboratory, where the Bobo Doll is; it was seen that the children played with Bobo Doll with the exact behavior of the model. It has been observed that the behaviors of the model such as; hammering, tossing, kicking and throwing on ground and beating / pounding etc., were similarly imitated by the children. Children's use of aggressive language while playing with Bobo Doll is another interesting subject. Albert Bandura presented important data on observational learning through this experiment.

Based on Albert Bandura's studies on observational learning, it is possible to comment on the visual culture which we face and feel in the present century's daily life. If we consider visual culture as an environmental factor, it does not seem possible for individuals to not observe this culture or to not reflect the traces of this culture on their behaviors in some way. It is observed that the famous characters observed in the visual culture such as; cinema, series, cartoons, fashion, social media etc., fields exhibit similar behaviors to the behavior of the model playing with the Bobo Doll toy in Bandura's experiment. It is thought that it is possible to explain the observed behaviors and the reflections on the behaviors of the observers through social learning. For this reason, the subject of social learning is discussed in this study in focus of our communication with visual culture, which is a social phenomenon. Before going into these discussions, it is considered necessary to determine the state of the subject of visual culture and how the visual culture is handled from this perspective.

\section{Visual Culture}

Visual culture is a multidisciplinary term that points to the increase of the visual forms with technological development in daily life such as; photography, painting, animation, graphic design, video etc. Although the history of visual communication with the produced images of human beings is based on the ancient times (Paleolithic Age), the term visual culture refers to the period after 1950's-1960's. In the postmodern world after 1950's-1960's, the relations of the individual with the visuals become more widespread through technology. The visual forms that surround socio-cultural life are in constant interaction and communication with people. Today, these forms can be encountered in many different topics, content and areas, such as; in a form of a weekend discount of a market, presentation of a film, exhibition or concert, representation of a fashion of the period, visual designs that address a social issue etc. Upon the subjects and various fields it applies to, Mirzoeff (2009) stated as "visual culture is everywhere; all around us are screens on computers, game consoles, iPods, handheld devices and televisions, far outnumbering those used by the still-healthy cinema industry" (p. 2). 
Although we encounter visual culture in such forms like; image, photo, video and animation, it is thought that it would be wrong to discuss visual culture only based on visual forms. Because the visual forms, presents us the meaning of visual culture by what is meant by the 'visual'. So, what is the meaning of the word 'culture'? Malcolm Barnard is the first name we come across in relation to this question. Whilst explaining the concept of visual culture, Barnard (1998) mentioned the terms 'visual' and 'cultural'. According to Barnard 'the visual' contains that everything can be seen and Barnard examines this concept under tree main topics: 'Everything produced or created by humans that can be seen', 'Functional or communicative intent: design' and 'Aesthetic intent: art' (Barnard, 1998). We can say that what Barnard means by 'the visual' equals visual forms like painting, sculpture, ceramics, photography, poster, video, animation and etc. Upon 'the cultural' concept, it is seen that Barnard explained it through titles of Kenneth Clark's Civilisation, Deyan Sudjic's Cult Objects and Ted Poldhemus's Streetstyle. With the concept of 'the cultural' it is seen that Barnard basically focuses on culture and the social phenomena covered by it (Barnard, 1998). The issues related to the production, distribution and reception of image in social structure and power-status relations are among the meanings that constitute the content of 'culture' in visual culture. Although Barnard tries to explain the visual culture on the axis of these concepts, he states that one-dimensional explanation cannot be made through these concepts due to the deep content of the visual and cultural concepts (Barnard, 1998, pp. 30-31). Therefore, the deep content of the concept of culture is the most important factor that reinforces this explanation.

There are many views on the concept of visual culture. Media, culture and communication researcher Mirzoeff (2009) points to the fact that visual culture is not only a subject in the context of the image object, but also a comparative literature area such as languages (English, French, Spanish, etc.). For this reason, Mirzoeff's (2009) approach to the concept of visual culture is based on meanings of gender, war, slavery, belief, race, etc., acquired by social factors in images. Another example; Howells and $\mathrm{Ne}$ greiros (2015) approach to the concept of visual culture through the use of visuals. In the studies of researchers such as Duncum (2001, 2002), Freedman (2000), Tavin and Hausman (2004), Tavin (2005) etc., it is seen that the subject of visual culture was examined in relation to art education. It is possible to reproduce the approaches on the concept of visual culture with these and similar examples. However, as it is understood from all these explanations, the main subject of visual culture is the visual forms which are human production and the relations of these forms with the follower. The main issue that comes to the fore in the relations of the visuals with the follower can be said to be 'meaning'.

Visual contain manly forms of meanings according to the forms for production purposes; social and individual values, thoughts, beliefs and ideologies. Through picture, photo, video, animation, graphic design etc., it is possible for individuals to gain achievements through observational and cognitive contexts. Experiencing sensual pleasures by looking at an oil painting, wanting a commodity over an advertising poster or learning about a subject by watching a documentary are examples of the meanings that the visual language presents to the audience. The content of images and the acquisition of meanings through visualization raise the issue of 'learning through observation'. Especially in the age of technology, it is seen that these questions are at the top of the topics that concern the concept of visual culture such as; how we look at the images, how often we look at visual, what we get from the visuals, the reflections of the visuals, their reflection on our behaviors etc. In this study, Çakır (2014) states that "problem visual culture deals with the question of how a person sees, what he sees and, why he sees it that way" (p. 166).

The fact that the concept of visual culture shows a multidisciplinary concept enables us to look at the content of the concept from a broad perspective. The main reasons of this situation can be shown as the disciplines (philosophy, communication, history, sociology, anthropology, pedagogy, etc.) that are interested in visual culture have different scientific foundations and research subjects. Again, it is seen that the effects of environmental factors on image production are among the factors that broaden the content and direction of the concept. This feature which is possessed by visual culture is an element that makes the examination of the concept difficult. Therefore, in studies on visual culture, it is important to determine in which ways the concept is being examined in terms of the scope of the concept. In this study, the concept of visual culture is discussed in the context of the intense relationships of the visuals we encounter in daily life with the follower and the meanings that these relations have on the follower. In this study, it is tried to examine the reflections of visuals that have various meanings related to visual culture concept in the context of social learning.

Modeling in Social Learning and Visual Culture Oriented Focus on Modeling

People can take the people they see in their social environment and their behaviors as a model for their own behaviors. This situation is also known as one of the most basic methods that people use to develop their own behaviors. In this regard, Bandura (1977) stated his views as "...most human behavior is learned observationally through modeling: from observing others one forms an idea of how new behaviors are performed, and on later occasions this coded information serves as a guide for action" (p. 22) in his study. As we understand from his expression, model is a guide. The behavior of the model provides observers with preliminary information about the effect, direction and outcome of the behavior. It is possible to give 'mother and father, children role model' saying as an example on this subject. Because parents are the most easily observed individuals by children. It is another example that teachers' behaviors can show a model to students. Models can be not only well-known and reliable figures such as parents, siblings, teachers but also the individuals and their behaviors we do not know much about. Especially in the context of visual culture, through visual media, people who are known or presented with the concepts of popularity, fame and reputation, and their behaviors can receive wide acclaim. This situation emerges as an imitation of the behaviors of famous individuals through modeling by means of visual culture forms.

Analyzing the models and models in relation to visual culture in the context of television and social media images makes it possible to provide more illustrative examples on the subject. The television or social media images in which we communicate in everyday life present many models of behavior to observers in the context of social learning. Considering model's features of being liked, pleasant, successful and with high status (Kalkan, 2011), examples that meet these characteristics are frequently encountered in both television and social media images. This is an example of the fact that the people we perceive through observation in television, movies, series, talk shows, and advertising programs have a wide mass of acclaimed physical and behavioral characteristics.

Individuals' appearances in television programs or social media accounts can give various meanings to people who respect, appreciate or love them. In other words, the physical appearance of famous individuals in television 
programs, their eating habits, cultural and sporting activities etc., features can be imitated as model behaviors by others. A similar situation can be exemplified in the context of shared images through social media accounts. Images shared on social media can provide various information to the observer about the behavior of the person sharing. Therefore, the behaviors of a social media user through images can be imitated by modeling by some observers. On this topic, it is possible to illustrate the social media stream with keywords \#IceBucketChallenge (to challenge ALS with icy water). The videos of the world-famous names (Mark Zuckerberg, Justin Bieber, Will Smith, Hilary Swank, etc.), which they shared through social media, have reached large audiences within a short time and created a certain awareness of ALS disease. Following the world-famous names, many famous or non-famous names imitated the same behavior through social media and attracted attention to ALS disease. Also in Turkey, this situation led many famous names imitate the same behavior in social media. With regard to social learning, it is thought that these famous names, which have model characteristics for many people, have important roles in the behaviors they exhibit through social media, both to mimic behavior and to spread the subject to wide masses. Another example on the subject can be modelling from the TV series. Erjem and Çağlayandereli (2006) focusing on modeling from TV series; revealed that young people are affected by the characters they observed in the domestic TV series. Thus, it is possible to adduce the television series about high school and school life that corresponds to adolescence. It is thought that the school series related to the fun and funny aspect of visual culture may have various reflections on the behaviors of observing adolescents. The inclusion of exaggerated elements in the visual expression of such series can be presented to the observer, which is not related to real school life. Observers, associating the behaviors of characters in such series with their own behaviors, can mimic the behavior of the characters they observe in their real school lives. It is possible to duplicate similar samples associated with the subject. But the common feature in all these examples, is the role of social learning on the meaning of visual discourse in relation to visual culture.

\section{Discourse and Model in Advertising Images}

It is difficult to say that the images of television and social media always reflect natural and real situations. For this reason, the meanings of these images can also awaken unrealistic meanings on observers. It is thought that the presentation of the behavior to the observer with an exaggerated expression through visual forms, which would not be effective in model selection under natural conditions, may cause the behavior to be perceived as model behavior. This situation shows itself more clearly in advertising images. As Berger (1977) stated, "And publicity is the process of manufacturing glamour" (p. 131). The unreal and exaggerated elements in advertising are a basic feature used in strengthening the narrative. It is inherent in advertising to arouse interest for a commodity to sell it to the consumer. These elements of attraction are the idealization of the human figures in the advertising image and the popular aesthetic appreciation (Leppert, 2009). On this topic, Leppert (2009, pp. 15-16) states that the exaggerated elements in the advertising images and the information about the promise of happiness have the power to guide the behavior of the observers. In order to influence the observers in the formation of these effects, it is important to include elements with model features in the discourse of advertising images. Muscular, charismatic, handsome men and beautiful, thin and sexy women representations we see frequently in advertising images (Leppert, 2009), are some of the physical images and meanings that have the model features presented to the observers. It can also be stated that these samples reflecting the model characteristics in the advertisements vary according to the age of the observer population. In order to appeal to children, the use of images like famous athletes, superhero, cartoon hero, fairy, knight, magician, princess, etc., is associated with this situation. Such images are among the factors that reinforce the influence on children's perceived behaviors through observation. In view of the frequency of visual communication in daily life with advertising images associated with all these situations, the information we get from advertising through observation brings out the relationship between social learning and visual culture.

The Relation of the Basic Principles of Social Learning Theory with Visual Culture

There are six basic principles of social learning theory (Bandura, 1977). These are reciprocal determinism, symbolizing capability, forethought capability, vicarious capability, self-regulatory capability and self-reflective capability (Bandura, 1977). Because social learning emphasizes learning by observing others (Woolfolk, 2015, p. 702), the dimensions of learning from others are associated with these six principles. In this section, social learning and visual culture relations are tried to be discussed within the framework of these basic principles.

Reciprocal determinism, one of the basic principles of social learning theory, states that personal factors, environmental factors and behavior are in interaction with each other (Bandura, 1977). In addition to the fact that the individual can be affected by environmental factors, this means that he / she can affect environmental factors (Bayrakçı, 2007; Kalkan, 2011; Senemoğlu, 2012). Here, the concept of the environmental factor refers to the socio-cultural environment with which the individual establishes a relationship by observation. Today, the world of visual culture has a socio-cultural structure in itself. It is observed that the development of image-oriented social networking and internet technology has transformed visual culture into a private living space. For this reason, visual culture forms represent a special environmental factor area that provides observers with information on many subjects and content.

It is possible for people to observe their environment in their daily lives as well as through visual culture forms. For example; it is possible for someone who never had been in Egypt to learn much about the Pyramid of Cheops by watching a comprehensive documentary on it. Likewise, a TV series about a famous King who lived in ancient times and his life is likely to offer a variety of information to the observers about the King. TV series, documentaries, movies, videos, photos, pictures etc., many visual culture forms are among the environmental factors that an individual communicates through observation. The 21st century technology and the visuality the technology offers to humans has not only facilitated people's access to information through images, but also created a new world order created with images. For this reason, people can acquire various information, behaviors and sensations from visuals and they can affect other people with the visuals they produce. In particular, it is thought that the visual field associated with social media has a close relation with the subject.

Bandura states that people are in cognitive interaction with the environment and they see the environment as a symbol of mind in cognitive representations. (Kalkan, 2011; Senemoğlu, 2012). In addition to understanding the environment, it is seen that the symbolizing capacity of people also helps them to regulate environmental conditions (Bandura, 1999, p. 27). "By using symbols such as images (mental images) or words, people give meaning, shape and continuity to their lives" (Bayrakçı, 2007, p. 205). In the context of visual culture as an environmental factor, it is thought that people's communication with images in countless meanings and content has various reflections on their mental symbols. For example, when we question the image of our mind on the physical appearance and dimensions of the ideal human (male / female), we realize that the image that appears 
in our mind is related to the images that visual culture presents to us. In other words, it is understood that the ideal human appearance and size created by the fashion world through images correspond to the image of the ideal human profile in our minds. Similarly, it is possible to say that the images shaped in our minds about the socio-cultural life of the future are images related to the visual forms presented by the cinema industry. Images created by science fiction movies about our future can help us to have ideas on cases like future technology, fashion, lifestyle etc. In part, it is possible that the visual culture will be able to serve the future of socio-cultural life by means of the images it creates in the mind. It is also possible to relate this situation to the foresight capacity, which is another principle of social learning. Foresight capacity means regulating and planning future experiences by taking advantage of experiences. Visual culture forms can present experiences to the observer through visuals. For this reason, vicarious information and experiences acquired through visual forms can be the basis for our future experiences. For example; the behavior of the models in the films or series that we perceive through observation, and the consequences of these behaviors can be an effective factor in directing our own behaviors. This is because it is thought that such examples, which we perceive through visual culture forms, have important roles on the formation of our mental symbols.

Another important principle of social learning is vicarious learning theory. Vicarious learning means that the individual can learn by observing other than his / her own experiences (Bayrakçı, 2007; Kalkan, 2011; Senemoğlu, 2012). In this study, vicarious learning is seen as the most important factor that emphasizes the relationship between social learning and visual culture. People can learn through visual forms if they can learn from others through observation. Because visuals are forms that offer vicarious experiences to people. Rather than two-dimensional visual forms like photo, picture, graphic design, advertising posters and etc., it is thought that especially the moving visual forms of the video genre have more decisive and effective roles. Because the moving visual forms in the video genre offer a more open narrative to the observers about how to associate a certain content with real experiences and to observe the result (reward / punishment) of the behavior they watch. One of the reasons for using educational videos in educational environments is related to vicarious experiences acquired from the visuals. Again, it is thought that visuals shared through social media accounts provide vicarious experiences to observers about the behaviors of the observed model. For example, the effort to be visible on social media is thought to be the result of vicarious learning acquired from others through social media. This does not mean that vicarious experiences from visuals always have a direct effect on learning. Although environmental factors may have important effects on learning, people can control their own behaviors through their own thought filters. People organize vicarious experiences through visuals by their self-judgment and self-reflection capacity.

Self-judgement and self-reflective capacities in social learning are concepts related to controlling, evaluation and regulation of individual's own behavior (Bayrakçı, 2007; Kalkan, 2011; Senemoğlu, 2012). Social learning, although it focuses on the relationship between environment and individuals, does not ignore the role of the individuals' relations with themselves in the deed of behavior. For this reason, people do not imitate the behaviors they observe from the environment unconditionally, they are known to convert them into behavior by passing them through their thought filters. This also applies to vicarious experiences from visual culture forms. Vicarious experiences acquired from visual culture forms are transformed into behaviors by means of self-reflective and self regulatory capability of the individual. For example; It is seen that violent computer games have important roles on young people to show tendency to violence (Dolu, Büker and Uludağ, 2010). However, this does not mean that violent behaviors observed in computer games can be imitated without being questioned. Although visual forms of culture offer vicarious experiences to the observer, individuals are able to evaluate the behavior observed through self-judgment and self-regulatory capacities, and to be able to formulate and organize opinions about the outcome. Therefore, social learning draws attention to the role of mental factors in the formation of behavior in addition to the effects of the environment.

\section{Vicarious Experiences from Visual Culture Forms}

People organize and form their own behaviors on the basis of the results of the behavior of others (Bigge and Shermis, 2004, p. 165). The results of vicarious experiences acquired from the model have important roles in imitating the observed behavior. Positive reinforcements that conclude the behaviors, affirm the repetition of behavior to the observer, whereas negative results (punishment) provide reasons for not repeating the behavior (Kalkan, 2011). In the 21st century socio-cultural environment, one of the most important areas where vicarious experiences are acquired is the visual culture forms. Because visual forms of culture offer people vicarious experiences in various subjects and content. Therefore, it is possible to say that vicarious experiences acquired from visual culture forms have relations with the concepts of 'vicarious reinforcement, vicarious punishment, lack of punishment and vicarious emotion'. Because of the experiences acquired through observation through visual culture forms and their results motivate the observer to mimic the behavior of the model.

The first concept which is related to the vicarious experiences of visual culture forms is vicarious reinforcement. Vicarious reinforcement seems to mean regulating our own behaviors based on the experiences we get from the results of others' behavior through observation (Bandura, 1977). As Bandura (1977) stated "people can profit from the successes and mistakes of others as well as from their own experiences" (p. 117). It is possible to reach these experiences that we have acquired through the observation of the result of the behaviors through the visual culture forms in which we communicate in daily life. In particular, in television commercials, vicarious reinforcement traces are observed (Gredler, 2009). The elements that advertising uses in the language of visual discourse to influence a particular audience seem to have features that corroborate vicarious reinforcement. For example; the use of famous people instead of ordinary people in advertising, benefiting from elements of attraction such power, status, beauty and handsets, and giving a place to the elements of reward and success, etc., create vicarious reinforcements on the observers. It is observed that the vicarious reinforcement related to these features encountered in advertisements arouses positive feelings about being fit or achieving social status on observers (Gredler, 2009, p. 357). It is possible to evaluate this situation not only in the context of television commercials but also in the context of many visual culture forms ranging from social media accounts, television series, movies, internet videos, advertising posters to artistic paintings.

Visual culture forms provide behavioral consequences for vicarious punishment as well as vicarious reinforcement. Vicarious punishment can be expressed as being away from imitating or exhibiting the observed behavior in relation to the negativity or punishment observed as a result of the behavior of others (Gredler, 2009). In the visual culture, vicarious punishment forms are more com- 
mon in especially cinema films, educational videos, series and graphic designs etc. It is seen that especially the public service ad visuals on the subject offer vicarious punishment based behavior results to the observers. Public service ad visuals, which we frequently make contact with on television, in public transportation stations and in the streets are mainly related to health, human relations, social order etc., providing vicarious punishment information. Recently, the ill effects of smoking and the subject of passive smoking, which are frequently discussed in public spots, offer results to observers about the negativity of the result of behavior and vicarious punishment based experiences through visuals. However, there are cases where visual culture forms do not offer vicarious punishment behavior results to observers. Another important aspect associated with vicarious experiences subject is the lack of punishment and its relations with visual culture.

The absence of punishment is whence the negative behavior is not followed by punishment that observers believe that a negative behavior will not result in a punishment if repeated at different times (Gredler, 2009). Visual culture forms do not always give behavior to people about the subject and content related to real life. Behaviors to be punished in real life can be shown as ordinary or rewarding in visual culture. These situations are frequently encountered in violent computer games. A young child who observes that a game hero does not suffer from dangerous movements is likely to attempt to mimic the behavior in real life by thinking that this dangerous behavior will not result in a negative outcome. Therefore, the absence of punishment for negative behavior from visual culture forms is thought to cause this negative behavior to be interpreted as repeating in other settings as a result of the absence of punishment.

Another issue we get from the images through observation is vicarious emotion. It is seen that some emotions are not acquired congenitally but from the environment through observation (Kalkan, 2011, p. 255). It is possible to talk about the effects of visual culture on this subject. Especially the increase in the use of visual-oriented social media is a factor that promotes vicarious emotion act. Personal shares created through images can provide observers with vicarious emotion acquisition through the emotions of others. This situation shows itself more clearly in visuals associated with consumption culture. Because the images created on the basis of the ideology of consumption can cause vicarious emotion act towards artificial happiness on people. This discourse of artificial happiness refers to the state of feeling of having the latest meta model. As another example, it is seen that violent video games causes effects on children such as; negative emotionality, unresponsiveness, alienation and etc., (Dolu, Buker and Uludağ, 2010, p. 62). In this case, it is seen that human is related to vicarious feelings obtained from environmental factors.

\section{Conclusion and Recommendations}

The communication, we have established with the visuals created with the development of technology, increases rapidly. This increase in our communication with visual forms has changed the dimensions and direction of the learning subject through visuals. Vicarious experiences we get from visual forms in the context of social learning are on the rise along with the place of images in social life. Today, a lot of information can be quickly accessed through the visual-focused facilities offered by internet technology. Visual culture elements such as; Internet videos, documentaries, news, movies, serials, banners, pictures etc. are among the forms that provide access to information.

Images provide observers with information and experiences that include a variety of meanings. The language created by the visual forms through images transforms into meaningful information in the mind through the reception activity.
Therefore, the experiences that visual culture forms offer to the observers as environmental factors are very similar to the indirect experiences acquired through observation in real life. The results of the experiences obtained from the visual culture forms have the power to shape our behaviors such as the consequences of our vicarious experiences in social life. In this age, where we live a part of social life through visual-oriented social media platforms, the reflections of our meanings on our behaviors are inevitable. In addition, this situation has various effects on individuals' self, identity, visual perception and aesthetic preferences. Because the experiences presented through visual culture forms have a decisive role on the individual's relations with themselves and with the society.

It is seen that, one of the most important subjects of social learning is learning from the model (Bandura, 1977, 1995, 1999; Gredler, 2009). The model that draws attention to social learning and its features are frequently encountered in visual culture forms. Features in social learning theory such as; model, power, and gender among the model as well as models of popular, admirable and pleasant people, etc., (Kalkan, 2011) are frequently encountered in the characters in areas that features, visual culture in the context of cinema, series, TV show, advertising, public spot, etc. The fact that the visual media field has a mass field increases giving a place to the individuals that correspond to the model features. Individuals who are becoming more and more visible in visual culture can observe the behaviors of others by observing others and exhibit behaviors that will be model for others. For this reason, visual culture forms provide observers, experiences of exhibiting, observing and imitating behaviors with model characteristics.

Visual culture is a phenomenon that expresses the representation of social life through visual forms. For this reason, there are close relations between experience of visual culture forms and experience of social life. The realization of social learning through visual culture forms is related to the experiences acquired through observation as in social life. Therefore, it has been seen in the research that principles of social learning (reciprocal determinism, symbolizing capability, forethought capability, vicarious capability, self regulatory capability and self reflective capability) are related to learning from the visual culture forms. Again, in the context of social learning, the vicarious experiences of visual culture forms are in relationship with vicarious reinforcement, vicarious punishment, lack of punishment and vicarious emotion. Experiences acquired through observation or visual learning from visual culture forms are the factors shaping the attitudes and actions of individuals in social life. This situation has gained importance especially with the increase of the area occupied by the visual culture in daily life. In the study, it was seen that the study of visual culture as an environmental factor in the context of social learning will help to understand and illuminate the changing, transforming and derived aspects of human behavior in the 21 st century.

Based on this research, it is thought that the experimental studies that can be done for the relationship between social learning and visual culture in the future period will enable the development of different approaches to the subject. In this study, social learning and visual culture relations can be examined with a study that can be conducted on experimental and control groups (eg, the effect of social learning and visual culture based classroom activities on students' learning). Again, it is thought that specific dimensioned studies (eg, the effects of the acquired experiences on the bilateral relations in the cinema films) will allow for in-depth study of the relationship between social learning and visual culture. At the same time, educational institutions can contribute to the development of visual literacy levels of the individuals through pedagogical studies that can be done to resolve the meaning in the visuals, and this can create a pre-awareness on the acquisition of negative behaviors from visual forms. 
In the critical pedagogy in educational institutions; It is foreseen that the provision of education by using methods of semiotics, pedagogical criticism, reception and etc., analysis for visual culture forms will have effective results on conscious visual literacy.

\section{References}

Aristoteles. (2010). Politika (M. Tunçay, Trans.). İstanbul: Remzi Kitabevi.

Bandura, A. (1977). Social learning theory. Englewood Cliffs, NJ: Prentice Hall.

Bandura, A. (1995). Exercise of personal and collective efficacy in changing societies. In A. Bandura (Ed.), Self-efficacy in changing societies (pp. 1-45). New York, NY: Cambridge University Press.

Bandura, A. (1997). Self-efficacy: The exercise of control. New York, NY: W. H. Freeman \& Company.

Bandura, A. (1999). Social cognitive theory: An agentic perspective. Asian Journal of Social Psychology, 2, 21-41. https://doi.org/10.1111/1467-839X.00024

Barnard, M. (1998). Art, design and visual culture: An introduction. New York, NY: St. Martin's Press.

Bayrakcı, M. (2007). Sosyal öğrenme kuramı ve eğitimde uygulanması. Sakarya Üniversitesi Eğitim Fakültesi Dergisi, 14, 198-210. Retrieved from http://dergipark.gov.tr/download/article-file/115558

Berger, J. (1977). Ways of seeing. New York, NY: Penguin.

Bigge, M. L., \& Shermis, S. S. (2004). Learning theories for teachers (6th ed). Boston: Pearson.

Çakır, M. (2014). Görsel kültür ve küresel kitle kültürü. Ankara: Ütopya.

Dewey, J. (2004). Democracy and education an introduction to the philosophy of education. India: Aakar.

Dolu, O., Büker, H., \& Uludağ, ş. (2010). Şiddet içerikli video oyunlarının çocuklar ve gençler üzerindeki etkileri: saldırganlık, şiddet ve suça dair bir değerlendirme. Adli Bilimler Dergisi / Turkish Journal of Forensic Sciences, 9(4). 54-75. Retrieved from http:// www.academia.edu/20925172/Şiddet_içerikli_Video_Oyunlarının_Çocuklar_ve_Gençler_Üzerindeki_ Etkileri_Saldırganlık_Şiddet_ve_Suça_Dair_Bir Değerlendirme

Duncum, P. (2001). Visual culture: Developments, definitions, and directions for art education. Studies in Art Education, 42(2), 101-112. https://doi.org/10.10 80/00393541.2001.11651691

Duncum, P. (2002). Clarifying visual culture art education. Art Education, 55(3), 6-11. https://doi.org/10.1080/0 0043125.2002.11651489

Erjem, Y., \& Çağlayandereli, M. (2006). Televizyon ve gençlik: yerli dizilerin gençlerin model alma davranışı üzerindeki etkisi. Sosyal Bilimler Dergisi (C.Ü.), 30(1), 15-30. Retrieved from http://content.Ims. sabis.sakarya.edu.tr/Uploads/48770/42696/6189 (makale)_televizyon_ve_gençlik,_yerli_diziler.. gençlik.._model_alma..._m._ça-layandereli,_2006. pdf

Freedman, K. (2000). Social perspectives on art education in the U.S.: Teaching visual culture in a democracy. Studies in Art Education, 41(4), 314-329. https://doi. org/10.1080/00393541.2000.11651684
Gredler, M. (2009). Learning and instruction: Theory into practice (6th ed.). Upper Saddle River, New Jersey: Prentice Hall.

Howells, R., \& Negreiros, J. (2015). Visual culture (2nd ed.). Cambridge, UK: Polity Press.

Kalkan, M. (2011). Sosyal öğrenme kuramı. In Y. Özbay \& S. Erkan (Eds.), Eğitim psikolojisi (pp. 245-270). Ankara: Pegem Akademi.

Leppert, R. (2009). Sanatta anlamın görüntüsü imgelerin toplumsal işlevi (i. Türkmen, Trans.). İstanbul: Ayrıntı.

Miller, N., \& Dollard, J. (1979). Social learning and imitation. Westport: Greenwood Press.

Mirzoeff, N. (2009). An introduction to visual culture (2nd ed.). New York, NY: Routledge.

Özbay, Y. (2011). Bilişsel gelişim. In Y. Özbay \& S. Erkan (Eds.), Eğitim psikolojisi (pp. 131-148). Ankara: Pegem Akademi.

Senemoğlu, N. (2012). Gelişim öğrenme ve öğretim kuramdan uygulamaya. Ankara: Pegem Akademi.

Tavin, K., \& Hausman, J. (2004). Art education and visual culture in the age of globalization. Art Education, 57(5), 47-53. doi:10.1080/00043125.2004.116535 68

Tavin, K. M. (2005). Opening re-marks: Critical antecedents of visual culture in art education. Studies in Art Education, 47(1), 5-22. doi:10.1080/00393541.2005.1 1652810

Thorndike, E. L. (1911). Animal intelligence: experimental studies. New York: The Macmillan Company.

Vygotsky, L. S. (1978). Interaction between Learning and Development. In M. Cole, V. John-Steiner, S. Scribner, \& E. Souberman (Eds.), Mind in Society: The Development of Higher Psychological Processes (pp. 79-91). Cambridge, MA: Harvard University Press.

Woolfolk, A. (2015). Eğitim psikolojisi (D. Özen, Trans.). İstanbul: Kaknüs. 